DOI: $10.17951 / 1.2017 .15 .2 .65$

A N N A LES

UNIVERSITATIS MARIAE CURIE-SKŁODOWSKA

LUBLIN - POLONIA

VOL. XV, 2

SECTIO L

2017

Instytut Historii Uniwersytetu Marii Curie-Skłodowskiej w Lublinie

IZABELA PASTUSZKo

\title{
Nowoczesne planowanie przestrzenne na przykładzie planu ogólnego rozwoju Lublina z 1959 roku w kontekście wybranych osiedli spótdzielczych
}

Modern Spatial Planning as Exemplified by the Plan of General Development of Lublin in 1959 in the Context of Selected Cooperative Housing Estates

Miasto Lublin było podmiotem wielu analiz urbanistycznego rozwoju aglomeracji, czy też złożonych badań nad tkanką architektoniczną z wyodrębnieniem okresów i stylów, zarówno budynków istniejących, jak i tych niezachowanych ${ }^{1}$. Opisy historycznej zabudowy ośrodka wydają się bardzo obszerne, jednak szczegółowe studia nad powojennym rozwojem przestrzennym miasta $\mathrm{w}$ drugiej połowie wieku XX, wraz z jego celami oraz kierunkami - są szerzej rozwijane dopiero od niedawna. Jednym z bodźców jest odpowiedni upływ czasu, który pozwala spojrzeć z dystansem na propozycje projektowe urbanistów i architektów epoki PRL. Znajomość sytuacji polityczno-gospodarczej ubiegłego półwiecza jest w tym wypadku również nie bez znaczenia. Zaznaczyć należy jednak, że te prawie pięćdziesiąt lat socjalistycznej Polski nie było jednorodne, zarówno w ramach politycznego zarządzania państwem, jaki i wytycznych wobec urbanistyki, czy samego stylu projektowanych gmachów. Przez budownictwo PRL rozumiemy

\footnotetext{
${ }^{1}$ Por.: D. Kociuba, Lublin. Rozwój przestrzenny i funkcjonalny od średniowiecza do wspótczesności, Toruń 2011; H. Gawerecki, C. Gawdzik, Lublin. Krajobraz i architektura, Warszawa 1964, czy N. Przesmycka, Lublin. Przeobrażenia urbanistyczne 1815-1939, Lublin 2012.
} 
zarówno powojenny funkcjonalizm, socrealizm, późny modernizm, czy też postmodernizm, który pojawił się w końcowej fazie epoki ustrojowej². Wszystkie te style miały wpływ na Lublin, który znamy dziś. Tak jak w przypadku innych miast polskich $^{3}$ - istotną wydaje się każda dekada jego najnowszej urbanistyczno-architektonicznej historii, która w toku analiz ukazuje swoją odrębność stylową i programową od kolejnej, wnosząc swój wkład w unikatowość miasta.

Określając zakres tematyczny artykułu, poza wyborem chronologicznym, doprecyzowałam rodzaj formalny analizy architektoniczno-urbanistycznej. Jako przedmiot mojego zainteresowania wybrałam osiedla mieszkaniowe o charakterze spółdzielczym w kontekście planów rozwoju całego miasta ustalonych w Ogólnym planie zagospodarowania przestrzennego $\mathrm{m}$. Lublina z roku $1959^{4}$. Przykładem takiej architektury są inwestycje Lubelskiej Spółdzielni Mieszkaniowej (LSM) powstałej w 1957 roku $^{5}$. Z dzisiejszej perspektywy możemy zauważyć, że śmiałe projekty urbanistyczne poszczególnych osiedli, jak i całej późniejszej dzielnicy, są zapisem kooperacji rozwoju technologii budowlanych z próbami uchwycenia potrzeb ludzkich, jakie może wypełnić architektura i urbanistyka osiedlowa, wpisanych w plan zrównoważonego rozwoju miasta. Czy ten mariaż był udany? Czy humanistyczne postrzeganie projektowania zostało odzwierciedlone w późnomodernistycznych realizacjach dawnego obszaru lubelskich $\operatorname{Rur}^{6}$ ? Próba analizy relacji między metodą projektową a szeroko rozumianymi potrzebami człowieka zostanie podjęta w celu uzyskania odpowiedzi na pytanie, ile jest $\mathrm{w}$ tej modernistycznej ${ }^{7}$ architekturze inżynierii, a ile sztuki projektowania

\footnotetext{
${ }^{2}$ Por.: Budownictwo i architektura w Polsce 1945-1966, red. J. Zachwatowicz, Warszawa 1988.

${ }^{3}$ Duży zbiór artykułów w tej materii, a dotyczący różnych polskich ośrodków miejskich przynosi publikacja: Pod dyktando ideologii. Studia z dziejów architektury i urbanistyki w Polsce Ludowej, red. P. Knap, Szczecin 2013.

${ }^{4}$ Zob. szerzej: H. Bieniaszkiewicz, Historia lubelskiej Pracowni Urbanistycznej oraz E. Furgał, Ogólny plan zagospodarowania przestrzennego m. Lublina z 1959 roku, [w:] Lubelska Pracownia Urbanistyczna 1955-2005, Urząd Miasta Lublin, Wydział Strategii i Rozwoju, Lublin 2005.

${ }^{5}$ Zob. szerzej: Lubelska Spółdzielnia Mieszkaniowa, red. B. Dębiec-Kalinowska, Warszawa 1968 oraz 50 lat Lubelskiej Spółdzielni Mieszkaniowej, red. A. Zdunek, Lublin 2007.

${ }^{6}$ Nazwa Rury związana jest z tym, że przez ówczesne pola w 1506 r. zostały przeprowadzone drewniane rury wodociągowe. Ich zadaniem było dostarczanie wody z rzeki Bystrzycy do Lublina. W końcu XVIII w. zakładano na tych obszarach jurydyki klasztorne, które były własnością ziemskich zakonników i pozostawały niezależne od miejskiej władzy sądowniczej oraz administracyjnej. M. Denys, Źródła idei i drogi powstania Lubelskiej Spółdzielni Mieszkaniowej, [w:] 50 lat Lubelskiej Spółdzielni Mieszkaniowej..., s. 27.

${ }^{7}$ Modernizm - pod nazwą tą kryje się ogólne określenie prądów w architekturze i urbanistyce, które rozwijały się w praktycznie przez cały wiek XX. Ich cechą charakterystyczną było odejście od stylów historycznych i wszelkiej stylizacji. Architektura modernistyczna opierała się na no-
} 
ludzkiego życia? ${ }^{8}$ Naturalnym cenzusem czasowym analizy jest okres powstania LSM, a na ramy zamykające wybrano koniec lat 60 . XX wieku jako czas zmian na szczeblu państwowym, kiedy to wraz z nastaniem epoki gierkowskiej pojawiły się nowe wytyczne projektowo-gospodarcze wobec polityki mieszkaniowej.

Poddając rozważaniom problematykę lubelskich osiedla spółdzielczych ustalonego okresu w kontekście planów rozwoju całego powojennego miasta, należy nakreślić sytuację ogólną, odnoszącą się do nowego podejścia do polityki mieszkaniowej władz państwowych po październiku 1956 roku. Przywołania wymaga fakt, że we wcześniejszych latach Polski Ludowej spółdzielczość mieszkaniowa została praktycznie pozbawiana możliwości rozwoju. Posiadająca swoją przedwojenną tradycję była jednym z kluczowych elementów odbudowy w pierwszych latach powojennych, aż do zniwelowania jej roli w decyzjach normatywnych wraz z rokiem $1948^{9}$. Polityka ta okazała się jednak destrukcyjna dla gospodarki mieszkaniowej, co odzwierciedla statystyka - w latach 1950-1955 jedno nowe mieszkanie przypadało na cztery statystyczne rodziny ${ }^{10}$. Zaspokajanie potrzeb budowlanych przemysłu ciężkiego kosztem potrzeb bytowych ludności okazało się znamienne w skutkach.

Efektem powyższego stanu rzeczy było diametralne pogorszenie warunków mieszkalnych, w dużym stopniu dociążone napływem ludności wiejskiej do miast, co w przypadku Lublina miało kluczowe znaczenie i zostanie szerzej opisane w dalszej części artykułu.

Zmiana polityki władz nastąpiła w 1954 roku, kiedy to zdecydowano o wydaniu pozwolenia na prowadzenie działalności inwestycyjnej spółdzielniom mieszkaniowym ${ }^{11}$. Wraz z wprowadzeniem nowej polityki, której wyrazem są słowa

wej metodzie twórczej, która wywodziła formę, funkcję i konstrukcję budynku niemal wyłącznie $\mathrm{z}$ istniejących uwarunkowań materialnych, nadając w pierwszych latach szczególny prym funkcjonalności obiektu. Wraz z upływem lat, w różnych częściach świata modernizm ulegał przetworzeniom w związku m.in. z panującą sytuacją polityczną czy ekonomiczną, a także przemianami społecznymi, na które miał być przestrzenną odpowiedzią. Zob. więcej: Le Corbusier, $W$ stronę architektury, thum. T. Swoboda, Warszawa 2012 czy Le Corbusier, Urbanistyka, thum. T. Swoboda, Warszawa 2015, lub Oblicza modernizmu w architekturze, red. R. Nakonieczny, J. Wojtas-Swoszowska, Katowice 2013.

${ }^{8}$ Czytaj szerzej o problematyce utopii modernizmu na przykład w: P. Juszkiewicz, Cień modernizmu, Poznań 2013.

${ }^{9} \mathrm{~K}$. Madej, Spółdzielczość mieszkaniowa. Władze PRL wobec niezależnej inicjatywy społecznej (1961-1965), Warszawa 2003, s. 15-16.

${ }^{10}$ A. Andrzejewski, Polityka mieszkaniowa, wyd. 3 zmienione, Warszawa 1987, s. 168.

${ }^{11}$ Zob. szerzej: Uchwała nr 269 Prezydium Rządu z 8 maja 1954 r. w sprawie spółdzielni mieszkaniowych i zadań spółdzielczości w zakresie budownictwa mieszkaniowego - M.P. z 1954 r., nr A-59, poz. 792 . 
Władysława Gomułki z X Plenum KC PZPR: „Gdyby tylko trzecią część tej sumy, jaką wydatkuje ludność na wódkę, przeznaczyć stale, rokrocznie na budowę własnych mieszkań - sprawa rozwiązania trudności mieszkaniowych szybko ruszyłaby naprzód"12, stworzono warunki formalne oraz społeczne do ponownego rozwoju spółdzielczości mieszkaniowej na ziemiach polskich, przyznając się jednocześnie do niewydolności państwa w dziedzinie mieszkalnictwa ${ }^{13}$.

Druga połowa lat 50. XX wieku to także czas swoistej odwilży projektowej. Zniesiony zostaje socrealizm ${ }^{14}$, jako jedyny obowiązujący styl. Architekci, a tym samym urbaniści zaczynają wracać do modernistycznych założeń kształtowania zarówno przestrzeni miasta, osiedla, jak i samego budynku. Okres ten zapoczątkowuje dynamiczny rozwój planowania przestrzennego, ze szczególnym uwzględnieniem szczebli regionalnych ${ }^{15}$. Decentralizacja biur projektowych ma swoje odbicie również w Lublinie. Efektem zmian w polityce urbanistycznej kraju jest powołanie w 1955 roku lubelskiej Pracowni Urbanistycznej jako jednostki budżetowej przy Miejskim Zarządzie Architektoniczno-Budowlanym Prezydium Miejskiej Rady Narodowej, na której czele stanął urbanista Romuald Dylewski ${ }^{16}$.

Odrodzenie się spółdzielczości mieszkaniowej, ale przede wszystkim planowany powojenny rozwój Lublina, wymagały ustalenia właściwej koordynacji przestrzennej dla zagospodarowania miasta wraz z szerokim nakreśleniem linii zmian. Nowo powołana Pracownia Urbanistyczna przystąpiła do prac nad ogólnym planem zagospodarowania przestrzennego miasta $\mathrm{z}$ wyodrębnieniem $\mathrm{w}$ zakresie programu tzw. planu etapowego na około dziesięć pierwszych lat (do roku 1965) oraz perspektywy na rok $1980^{17}$.

${ }^{12}$ W. Gomułka, Sytuacja w partii i kraju. Referat wygtoszony na X Plenum KC PZPR 24 października 1957, Warszawa 1957, s. 49-50.

${ }^{13}$ Zob. szerzej: Madej, op. cit., s. 18-22.

${ }^{14}$ Socrealizm to kierunek w sztuce, określany jako metoda twórcza. W Polsce realizm socjalistyczny w postaci doktrynalnej istniał w latach 1949-1956. Zakładał, że dzieło sztuki powinno posiadać realistyczną formę i socjalistyczną treść, zgodną z ideami marksizmu i leninizmu. Zob. szerzej: W. Włodarczyk, Socrealizm: sztuka polska w latach 1950-1954, Kraków 1991.

${ }^{15}$ Zob. szerzej: Budownictwo i architektura w Polsce..., s. 17 i nast.

${ }^{16}$ Bieniaszkiewicz, op. cit., s. 16-19.

Romuald Dylewski, dr arch. urbanista, profesor nadzwyczajny w Instytucie Gospodarki Przestrzennej i Mieszkalnictwa w Warszawie, pracował m.in. w Biurze Urbanistycznym Warszawy. Ważniejsze prace urbanistyczne w kraju (generalny projektant): Plan Dzielnicy Przemysłowo Portowej Żerań w Warszawie (trzecia nagroda ministra); Plan Ogólny Rozwoju Miasta Lublina (pierwsza nagroda ministra); Plan Lubelskiego Zagłębia Węglowego (urbanizacji regionu). Ważniejsze prace urbanistyczne za granicą (generalny projektant): Plan rejonu West Bethnal Green w Londynie; Plan rozwoju miasta Bagdad i aglomeracji bagdadzkiej (honorowa nagroda ministra); Plan miasta Homs w Iraku; Plan Nowego Miasta Madina Al-Asad, w aglomeracji Damaszku, Syria.

${ }^{17}$ Furgal, op. cit., s. 35 i nast. 
Początkowe prace polegały na rozpoznaniu stanu istniejącego zagospodarowania terenu miasta oraz zebraniu wytycznych od organów planowania gospodarczego. Warto tu przywołać informacje zawarte w samym dokumencie planu, z których wynika, że urbaniści otrzymali dane tylko dla pierwszej pięciolatki, czyli na lata 1956-1960, a i te były niekompletne. Dla kolejnych pięciolatek, jak i wspomnianej wieloletniej perspektywy, skonkretyzowanych planów gospodarczego rozwoju Lublina nie było. Jedyną utrzymaną przez władze regionu hipotezą była potencjalna liczba wzrostu ludności do 250 tysięcy mieszkańców w roku $1980^{18}$.

Rozważając założenia rozwoju przestrzennego Lublina zawarte w planie ogólnym, należy przypomnieć kilka faktów związanych z powojennym zapotrzebowaniem na lokale mieszkalne w powojennym Lublinie, cofając się do lat 40 . XX wieku. Rozwój przestrzenny miasta wiązał się ściśle z powołaniem do życia w 1944 roku. Uniwersytetu Marii Curie-Skłodowskiej i rozpoczęciem budowy Dzielnicy Uniwersyteckiej (w 1949) ${ }^{19}$, jak też, a może przede wszystkim z powstaniem następujących zakładów przemysłowych (wynikających z założeń planu sześcioletniego): Fabryki Samochodów Ciężarowych, Lubelskiej Fabryki Maszyn Rolniczych, Zakładów Obuwia im. Mariana Buczka, Zakładów Mięsnych i Zakładów Piwowarsko-Słodowniczych. Rozbudowano również istniejącą już cukrownię. Spowodowało to napływ ludności ze wsi oraz małych miasteczek. W 1946 roku. Lublin liczył 99,4 tysięcy mieszkańców, w 1957 - 147 tysięcy, a w 1959 - prawie 170 tysięcy $^{20}$.

Zapotrzebowanie mieszkaniowe rosło, a budowa pierwszych powojennych zespołów mieszkaniowych - tzw. Zakładów Osiedli Robotniczych, popularnych ZOR-ów ${ }^{21}$ - przyniosła tylko znikomą liczbę lokali wobec stale rosnących potrzeb. Dziesiątki tysięcy lublinian nadal mieszkały w bardzo trudnych warunkach lokalowych, nierzadko w suterenach czy też mieszkaniach ze wspólną kuchnią $i$ toaletą lub nawet bez niej.

Wobec powyższych faktów twórcy planu rozwoju Lublina z roku 1957, przyjętego przez Komitet Urbanistyki i Architektury w dniu 21 grudnia 1959 roku ${ }^{22}$, wśród

${ }^{18}$ Ogólny plan zagospodarowania przestrzennego miasta Lublina, 1957 rok, Prezydium Miejskiej Rady Narodowej w Lublinie, Miejski Zarząd Architektoniczno-Budowlany, Archiwum Wydziału Planowania Urzędu Miasta Lublin, Akta Pracowni Urbanistycznej Miasta Lublina, nr 129/1., k. A-5.

${ }^{19}$ Zob. szerzej: I. Pastuszko, Architektura Dzielnicy Uniwersyteckiej w Lublinie, Lublin 2013.

${ }^{20}$ Zob. szerzej: Gawarecki, Gawdzik, op. cit., s. 62.

${ }^{21}$ Wzdłuż al. Racławickiej powstała Racławicka Dzielnica Mieszkaniowa z 1049 izbami, a w dalszej jej części osiedle ZOR-Zachód z 1192 izbami i ZOR-Bronowice z 3236, Denys, op. cit., s. 23.

${ }^{22}$ Furgal, op. cit., s. 37. 
założeń projektowych dużą uwagę skupili na potencjalnych terenach mieszkalnych. Zwrócili oni uwagę, że układ przestrzenny miasta z początku 1956 roku jest pełen chaotycznych i przypadkowo nakładających się funkcji miejskich. Efektem tego stanu rzeczy były poważne konflikty przestrzenne dla trzech podstawowych funkcji miasta: mieszkalnej, miejsc pracy oraz wypoczynku ${ }^{23}$. Frazy te kierują nas automatycznie do zasad nowoczesnego planowania miejskiego zawartych w Karcie Ateńskiej ${ }^{24}$, a jak wynika z opisu planu rozwoju Lublina - znanych i akceptowanych przez jego twórców.

Według wytycznych projektowych pochodzących z Karty, dzielnice mieszkalne powinny zajmować $\mathrm{w}$ układzie przestrzennym miasta najlepsze tereny, aby ich użytkownicy mogli korzystać $\mathrm{z}$ walorów rzeźby terenu, nasłonecznienia, klimatu i docelowej zieleni ${ }^{25}$. W Perspektywie planu rozwoju Lublina znajdujemy szczegółowy opis warunków mieszkalnych z podziałem na jego część północną i południową. Naturalną granicą konstytuującą te dwie strefy jest według dokumentu dolina rzeki Bystrzycy. Zarówno pod względem czynników zdrowotnych, funkcjonalnych, jak i walorów krajobrazowych część północna przewyższa południową, co powoduje, że tereny te zostają zaplanowane pod przyszłą zabudowę wielorodzinną. Przemawia za tym wyborem fakt, że obszar ten, pozbawiony w zasadzie przemysłu, integralnie związany z organizmem miasta istniejącego oraz Śródmieścia (w sytuacji gdzie część południowa oddzielona jest od niego doliną wspomnianej rzeki Bystrzycy), posiada jednocześnie wysokie przymioty widokowe terenu wzgórz dawnego obszaru Rur ${ }^{26}$. Konsekwencją tego jest zawarcie w ogólnym planie rozwoju miasta informacji o docelowym przekazaniu części tych trenów pod budowę spółdzielczych osiedli mieszkaniowych dla powstania dzielnicy Lubelskiej Spółdzielni Mieszkaniowej ${ }^{27}$.

Kluczowy dla powołanej Karty Ateńskiej podział na strefy jest konieczny w celu przypisania każdej z nich należytego miejsca w planie zagospodarowania terenu. Wiąże się to z ściśle ustaloną zasadą, że słońce, zieleń i otwarta przestrzeń są bezdyskusyjnymi wytycznymi nowej urbanistyki, które w przypadku

${ }^{23}$ Ogólny plan zagospodarowania przestrzennego miasta..., k. C-12.

${ }^{24}$ Karta Ateńska - przyjęta w 1933 r. przez czwarty Congrès international d'architecture moderne (CIAM), sformułowała zasady funkcjonalnej urbanistyki. Wpłynęły one na urbanistykę i projekty odbudowy miast po 1945 r. Szerzej zob. Grupa CIAM-Francja, Karta Ateńska. Urbanistyka C.I.A.M., tłum. K. Szeronos, oprac. J. Choroszucha i S. Maciąg, Koło Naukowe Wydziału Architektury Wnętrz ASP, Warszawa b.r.w., zwana dalej Kartą.

${ }^{25}$ Ibid., s. 43 i nast.

${ }^{26}$ Lublin - Plan zagospodarowania przestrzennego. Etap - Perspektywa. Tekst syntetyczny, Lublin 1957, Archiwum Wydziału Planowania Urzędu Miasta Lublin, Akta Pracowni Urbanistycznej Miasta Lublina, akta nieskatalogowane, k. 3.

${ }^{27}$ Ogólny plan zagospodarowania przestrzennego miasta, k. C-14. 
projektowania osiedli stają się bezwzględnymi ${ }^{28}$. Kolejną regułą, pochodzącą ze wspomnianego międzynarodowego zbioru zasad projektowych, jest ustalenie rozdziału mieszkalnictwa od komunikacji. Budynek mieszkalny winien być osadzony na wolnym terenie, z dostępem do wspomnianego już słońca, świeżego powietrza oraz ciszy. Układ taki wprowadza automatyczne rozdzielenie ruchu miejskiego na szlaki powolnej komunikacji pieszej oraz drogi ruchu szybkiego przeznaczone dla pojazdów mechanicznych ${ }^{29}$. Plan ogólny Lublina z 1959 charakteryzuje zaprojektowanie bezkolizyjnych arterii szybkiego ruchu, przebiegających dolinami rzek, czy wyraźnymi jarami daleko od zabudowy mieszkalnej, dodatkowo izolowanej zielenią. W taki sam sposób projektowano również drogi dojazdowe do nowo planowanych osiedli ${ }^{30}$.

Kolejnym założeniem Karty Ateńskiej, zbieżnym z planem rozwoju Lublina, jest zakres usług w zespołach mieszkalnych. Dokument nowej urbanistyki odwołuje się głównie do problemu braku szkół na terenach osiedlii ${ }^{31}$, natomiast twórcy planu rozwoju miasta podchodzą do tematu w sposób bardziej komplementarny. Zakładają zarówno budowę przedszkoli, jak i szkół w nowo powstających zespołach mieszkalnych, ale także utworzenie ośrodków dzielnicowych umożliwiających codzienne zakupy wszelkich artykułów spożywczych czy przemysłowych powszechnego użytku, bez potrzeby dojazdu do Śródmieścia ${ }^{32}$. Jest to nowe podejście w planowaniu założeń przestrzennych Lublina, gdyż wcześniej usługi nie były dla wszystkich mieszkańców jednakowo dostępne. Uprzywilejowani byli zdecydowanie lokatorzy rejonów centrum, które stanowiło główną koncentrację usług w mieście, a zaniedbane, peryferyjne dzielnice pozbawione ich były prawie zupełnie. Nowy plan Lublina zakładał budowę dużej ilości obiektów usługowych, zarówno tych handlowych, kulturalnych, jak i oświatowych - we wszystkich nowo projektowanych dzielnicach mieszkalnych ${ }^{33}$.

Przedstawione założenia projektowe dla osiedli mieszkaniowych zawarte w nowym planie miasta Lublina wydają się pełnym odzwierciedleniem słów pochodzących z Karty:

${ }^{28}$ Grupa CIAM-Francja, op. cit., s. 32.

${ }^{29}$ Ibid., s. 35-36.

${ }^{30}$ Ogólny plan zagospodarowania przestrzennego miasta..., k. C-63 i nast.

${ }^{31}$ Grupa CIAM-Francja, op. cit., s. 38.

${ }^{32}$ Lublin - Plan zagospodarowania przestrzennego. Etap 1956-65. Plan syntetyczny, Lublin 1957, Archiwum Wydziału Planowania Urzędu Miasta Lublin, Akta Pracowni Urbanistycznej Miasta Lublina, akta nieskatalogowane, k. 17 i nast.

${ }^{33}$ Zob. szerzej: R. Dylewski, O urbanistyce, planach i perspektywach Lublina, ,Kalendarz Lubelski” 1962, nr 5 po wznowieniu, s. 57-58. 
„Jeśli komórka jest pierwszym elementem biologicznym to ognisko domowe, czyli miejsce schronienia rodziny, stanowi komórkę społeczną. Budowa tego ogniska $[\ldots]$ powinna stać się przedsięwzięciem humanistycznym. Ognisko domowe jest początkowym jądrem urbanistyki. Osłania ono wzrost człowieka, daje schronienie radościom i smutkom codziennego życia" ${ }^{\prime 3}$.

Ta humanistyczna inżynieria przestrzeni najbardziej widoczna wydaje się być na przykładzie nowo powstających osiedli Lubelskiej Spółdzielni Mieszkaniowej, w szczególności dwóch pierwszych, to jest os. imienia Adama Mickiewicza oraz os. imienia Juliusza Słowackiego. Samo powołanie do życia LSM nastąpiło relatywnie szybko w stosunku do innych ruchów spółdzielczych w powojennej Polsce. Prace formalno-organizacyjne trwały krótko, a pierwsze posiedzenie Komitetu Organizacyjnego Spółdzielni odbyło się już 27 marca 1957 r. Określono terminy działań, które to zostały podzielone na cztery sekcje: statutowo-organizacyjną, lokalizacyjno-dokumentacyjną, finansów oraz wykonawstwa i zaopatrzenia materiałowego. W dniu 25 kwietnia 1957 r. w Sali Kolumnowej Urzędu Wojewódzkiego w Lublinie odbyło się Walne Zebranie Założycielskie Spółdzielni Mieszkaniowej, na którym obecnych było czterdziestu członków założycieli ${ }^{35}$.

Na czele pierwszego zarządu Lubelskiej Spółdzielni Mieszkaniowej stanął Stanisław Kukuryka ${ }^{36}$ - wieloletni prezes, a statut LSM zarejestrowano w Sądzie Powiatowym w Lublinie 8 maja 1957 r. Według jego brzmienia członkiem spółdzielni mogła być osoba fizyczna, zamieszkała na stałe w Lublinie i utrzymująca się z pracy własnej, ewentualnie pobierająca zaopatrzenie z funduszy publicznych. Niezwłocznie przyjęto również plan działalności, który przewidywał zbudowanie w latach 1958-1960 (w tzw. pierwszym rzucie) trzech tysięcy izb mieszkalnych. Na wykonawcę projektu wybrano Społeczne Przedsiębiorstwo Budowlane, a koszt szacowano na 120 milionów złotych ${ }^{37}$.

Przystąpienie do działalności inwestycyjnej poprzedził etap projektowy, będący w przypadku wybranych osiedli kluczowym dla tematu prowadzonych rozważań, czyli społecznej inżynierii przestrzeni. Do zaprojektowania pierwszego z osiedli LSM - imienia Adama Mickiewicza - władze spółdzielni zaprosiły architekta

${ }^{34}$ Grupa CIAM-Francja, op. cit., ss. 117-118.

${ }^{35}$ Lubelska Spółdzielnia..., s. 28

${ }^{36}$ Stanisław Kukuryka (1928-2010) - prawnik. W latach 1972-1982 pełnił funkcję prezesa Zarządu Centralnego Związku Spółdzielni Budownictwa Mieszkalnego, a od 9 października 1982 roku do listopada 1985 roku ministra budownictwa i przemysłu materiałów budowlanych w rządzie Wojciecha Jaruzelskiego. W latach 1976-1985 był posłem na Sejm, a później ambasadorem w Libii.

${ }^{37}$ Załącznik do protokołu walnego zgromadzenia założycielskiego z 25 IV 1957 r. [w:] Lubelska Spótdzielnia..., s. 28 
Feliksa Haczewskiego ${ }^{38}$ i to właśnie podejście projektowe w ustalaniu kształtu jego zabudowy jest odzwierciedleniem tez zawartych w temacie. Doskonale obrazują to słowa samego architekta:

„W roku 1957 po raz pierwszy chyba można było przystąpić do projektowania osiedla mieszkaniowego dla nieanonimowych mieszkańców. Można było rozmawiać z tymi, dla których projektowało się mieszkanie, usługi, zieleń; to wszystko, co składa się na osiedle mieszkaniowe. Spółdzielca, wnosząc w swe przyszłe mieszkanie pełny jego koszt, był kimś zupełnie innym niż petent otrzymujący w prezencie od kwaterunku mieszkanie według kolejności z listy, bez możności jakiegokolwiek wyboru czy to ulicy, budynku, kondygnacji czy też mieszkania. Zainteresowania spółdzielców nie ograniczały się wyłącznie tylko do sprawy własnego mieszkania. $Z$ wielkim ożywieniem wyrażali swe poglądy i życzenia we wszystkich sprawach związanych z osiedlem" ${ }^{\prime 39}$.

Haczewski stworzył pełną infrastrukturę do życia mieszkańców. Wzniesiono pięćdziesiąt trzy ceglane bloki o czterech lub pięciu kondygnacjach, a także kilku wieżowców na obrzeżach osiedla, gdzie znalazło się również miejsce dla kotłowni i parkingów. W ramach infrastruktury społecznej obsługi powstało przedszkole, żłobek, przychodnia, szkoła oraz obiekty handlowe. Całość wybudowano w latach 1958-1969 40. $^{2}$.

Szczególnie istotnym zabiegiem podjętym dla określenia społecznych potrzeb przyszłych mieszkańców, wobec tworzonego zaplecza osiedla, było przeprowadzenie ankiety wśród członków spółdzielni, która miała na celu ich zobrazowanie. Sam zaś architekt w swojej działalności projektowej wsparł się pomocą różdżkarzy, w osobach ojców kapucynów, aby sprawdzić rozkład występowania oraz przebiegu żył i cieków wodnych. Uzupełnienie przez Haczewskiego urbanistyczno-architektonicznego projektu o „ludowe” metody świadczyć może o potrzebie jak najpełniejszego, racjonalnego zaplanowania przestrzeni oraz świadomości projektanta, że ustalając kształt osiedla - ustala zasady życia ludzi w tej przestrzeni ${ }^{41}$.

${ }^{38}$ Feliks Haczewski (1907-1984) - architekt, radiesteta; absolwent Wydziału Architektonicznego Politechniki Lwowskiej (1934), projektant pawilonu usługowo-handlowego przy ulicy Rymwida 6 w Lublin (1957) oraz osiedla im. Adama Mickiewicza w Lublinie.

${ }^{39}$ Materiały 1957-1967, 8/6, I/6, F. Haczewski, Zasady projektowania osiedla im. A. Mickiewicza w Lublinie, Archiwum Lubelskiej Spółdzielni Mieszkaniowej, k. 1.

${ }^{40}$ Lubelska Spółdzielnia..., s. 42.

${ }^{41}$ Materiały 1957-1967, 8/6, I/6, F. Haczewski, Zasady projektowania..., k. 1-8. 
Istniejąca do dziś struktura urbanistyczno-architektoniczna osiedla im. Adama Mickiewicza w Lublinie jest wyjątkowym przykładem projektu powojennego masowego budownictwa mieszkaniowego, które możemy wskazać jako przykład humanistycznego myślenia o urbanistyce bytowej. Osiedle powstało z uwzględnieniem potrzeb jego przyszłych użytkowników, z troską o stworzenie im jak najbardziej przyjaznej przestrzeni do życia, w której każde mieszkanie uzyska dostęp do światła dziennego. Architektura ta jest pełna słońca, wyjątkowej zieleni (projektu inż. Józefa Maciejewskiego) i otwartej przestrzeni, a pawilony sklepowe rozmieszczono w taki sposób, aby każdy z mieszkańców nie musiał pokonywać drogi dłuższej niż 150 metrów ${ }^{42}$. Wciąż widoczny jest fakt, że mimo dużej liczby budynków i rozległej kubatury osiedla nie zgubiono tu skali człowieka.

Drugim projektem LSM, który pochodzi z omawianych gomułkowskich lat, jest osiedle imienia Juliusza Słowackiego, zrealizowane w latach 1964-1970. Twórcą tego projektu jest Oskar Hansen ${ }^{43}$ wraz z żoną Zofią ${ }^{44}$. Kontekst projektowania osiedla Słowackiego jest mocno osadzony w politycznych i gospodarczych realiach lat sześćdziesiątych ubiegłego wieku. Architekt, wprowadzając długie linearne bloki okalających wzgórze, na którym zbudowano ten zespół mieszkalny (tzw. falowce), starał się wpisać w coraz mocniej widoczne tendencji do obniżania kosztów budownictwa. Znamienne jest to na przykładzie oczekiwanej gęstości zaludnienia. Wytyczne dla osiedla imienia Adama Mickiewicza zakładały trzysta sześćdziesiąt osób na hektar, na wybudowanym zaś zaledwie kilka lat później na tzw. osiedlu Słowackiego musiało powstać prawie dwa razy więcej mieszkań, gdyż norma wymagała zakwaterowania już sześćset sześćdziesięciu osób na jeden hektar ${ }^{45}$. Pomimo tych finansowych ograniczeń, architekci projektowali z ogromnym zaangażowaniem, próbując wcieli swoje teorie w praktykę.

Szczególnie mocno zarysowuje się w tym projekcie funkcjonalno-przestrzenna koncepcja terenu. Precyzyjnie rozdzielono cichą strefę rekreacji - zwaną tu obsługiwaną, od strefy obsługi mieszkańców - tak zwanej obsługującej. Osiedle znajduje się w północno-zachodniej części dzielnicy LSM, gdzie różnica

\section{${ }^{42}$ Ibid.}

${ }^{43}$ Oskar Hansen (1922-2005) - architekt, uczeń Fernanda Légera i Pierre'a Jeannereta, malarz, rzeźbiarz, teoretyk, profesor ASP w Warszawie, twórca teorii Formy Otwartej. Tę urbanistyczną filozofię po raz pierwszy przedstawił w 1959 r., na ostatnim Kongresie CIAM. Stała się ona przełomem w pojmowaniu układów urbanistycznych i konstruowaniu tkanki mieszkaniowej oraz w pojmowaniu relacji artysta - dzieło sztuki - odbiorca. Teorie Hansena znajdują zastosowanie w Bergen School of Architecture w Norwegii, założonej w 1983 r. przez jego ucznia Sveina Hatløya, która kształci architektów w myśl przywołanych idei.

${ }^{44}$ Denys, op. cit., s. 53-54.

${ }^{45}$ Ibid. 
poziomów wynosi nawet do dwudziestu dwóch metrów. Te krajobrazowe walory zostały doskonale wykorzystane w koncepcji przestrzennej osiedla w celu stworzenia optymalnie dobrych warunków życia ${ }^{46}$.

Wraz ze zmianami gospodarczo-politycznymi oraz wzrostem nacisków na tanie budownictwo, czego efektem stało się powszechne stosowanie prefabrykatów w osiedlach pochodzących z lat siedemdziesiątych dwudziestego wieku, jakość kolejnych realizacji LSM była coraz niższa. Przede wszystkim mowa tu jednak o technologii budowy, warto jednak podkreślić jakość projektu urbanistycznego całej dzielnicy, który jest przykładem bardzo racjonalnego budownictwa mieszkaniowego czasów PRL.

Wytyczne polityczno-gospodarcze, którym musieli sprostać urbaniści i architekci czasów PRL, bywały zasadnicze, wyśrubowane oraz często nie w duchu humanistycznego projektowania miejskiego. Jednak to właśnie świadomość projektantów decydowała o ostatecznym układzie nowo powstałej dzielnicy czy osiedla. Efektem ich otwartości na potrzeby ludzi, którym projektowali przyszłe życie wśród budynków, a także rezultatem znajomości nowoczesnego podejścia do tworzenia przestrzeni miejskich, pomimo centralnych zaleceń - są wartościowe i wciąż aktualne relacje przestrzenne powstałych osiedli. Powojenny Lublina miał szczęście od świadomego i nakierowanego na człowieka myślenia o przestrzeni, które praktykował między innymi twórca powojennego planu rozwoju miasta urbanista Romuald Dylewski, czy też architekt Feliks Haczewski. Wydaje się, że ochrona tych dobrych rozwiązań projektowych w kontekście dzisiejszego ściśle finansowego podejścia do przestrzeni i sprzedaży mieszkań zasługuje na szczególną uwagę. Warto, aby Lublina zachował te dostosowane do potrzeb mieszkańców osiedla, nawet jeśli postrzega się je dzisiaj jako relikty minionej epoki.

Z dzisiejszej perspektywy można zauważyć, że śmiałe projekty urbanistyczne poszczególnych osiedli, jak i całej dzielnicy LSM, są zapisem kooperacji rozwoju technologii architektoniczno-budowlanych z próbami uchwycenia potrzeb ludzkich, jakie może wypełnić architektura. W efekcie, w późnomodernistycznych realizacjach na dawnym obszarze lubelskich Rur oraz w całym nowym projekcie miasta Lublina zostało odzwierciedlone humanistyczne postrzeganie projektowania. Można w nich widzieć przykład udanego mariażu inżynierii i sztuki projektowania wielowymiarowej przestrzeni ludzkiego życia.

${ }^{46}$ Zob. szerzej: Gawarecki, Gawdzik, op. cit., s. 71. 


\section{SUMMARY}

The latter half of the nineteen-fifties in Poland was the time of the abolishment of the socialist doctrine and considerable decentralization of spatial planning of towns and housing estates. The noticeable thaw in political life was also the period in which cooperative housing movements were restored. This was also the case with Lublin. The establishment of the Lublin Housing Cooperative (LSM) in 1957 was an answer to the housing needs of the time, which were strictly defined in the grand plan for the town developed in 1957, and adopted in 1959.

From today's perspective it could be observed that the bold urban development projects of individual housing estates as well as the whole LSM district are a record of the cooperation between the development of architectural-building technologies and the attempts to grasp human needs that can be fulfilled by architecture. As a result, the late modernist implementations in the former area of Lublin's Rury district and in the new urban project of Lublin reflected the humanist perception of town design. They can be regarded as an example of successful combination of engineering and the art of planning the multidimensional space of human life.

\section{Fotografie}

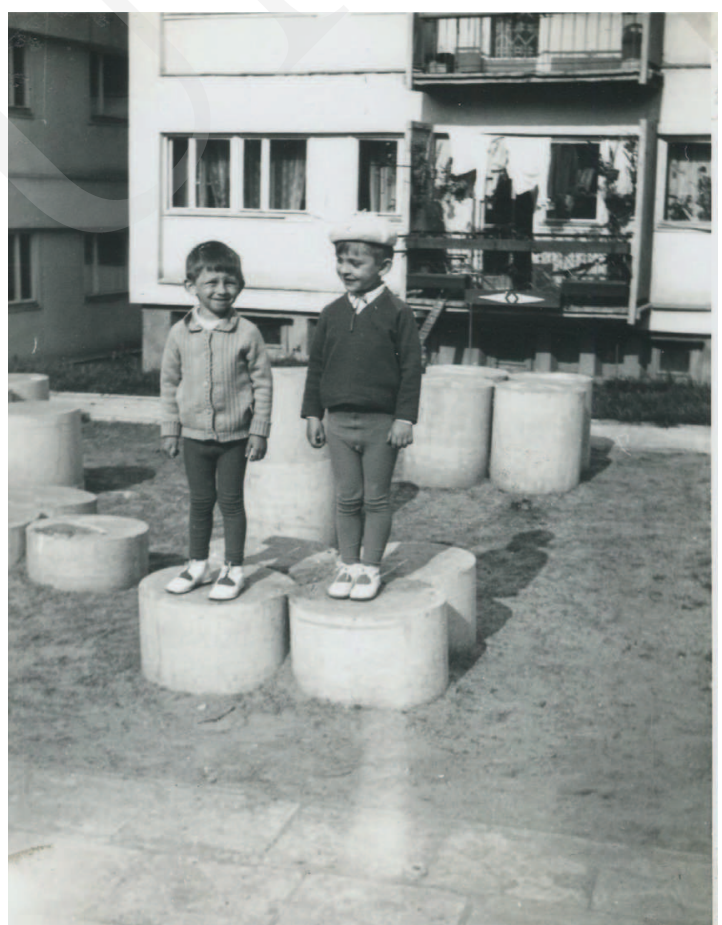

Fot. 1. LSM, ul. Balladyny, 1967; fot. ze zbiorów Zofii Siwek, własność Fundacji Lubelska Agora Modernizmu. 
Pobrane z czasopisma Annales L - Artes http://artes.annales.umcs.pl

Data: 26/04/2023 12:52:50

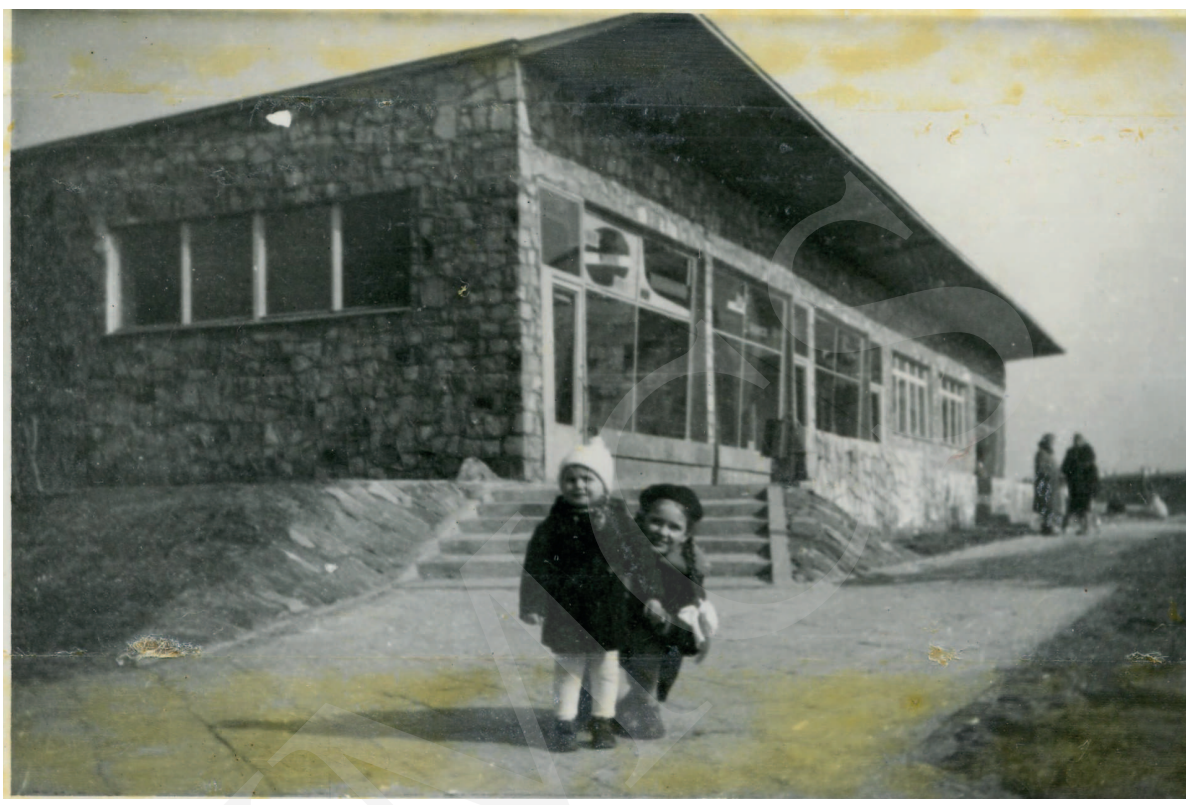

Fot. 2. LSM, os. Mickiewicza, pawilon przy ul. Grażyny, 1962; fot. ze zbiorów Danuty Wołyniec, własność Fundacji Lubelska Agora Modernizmu.

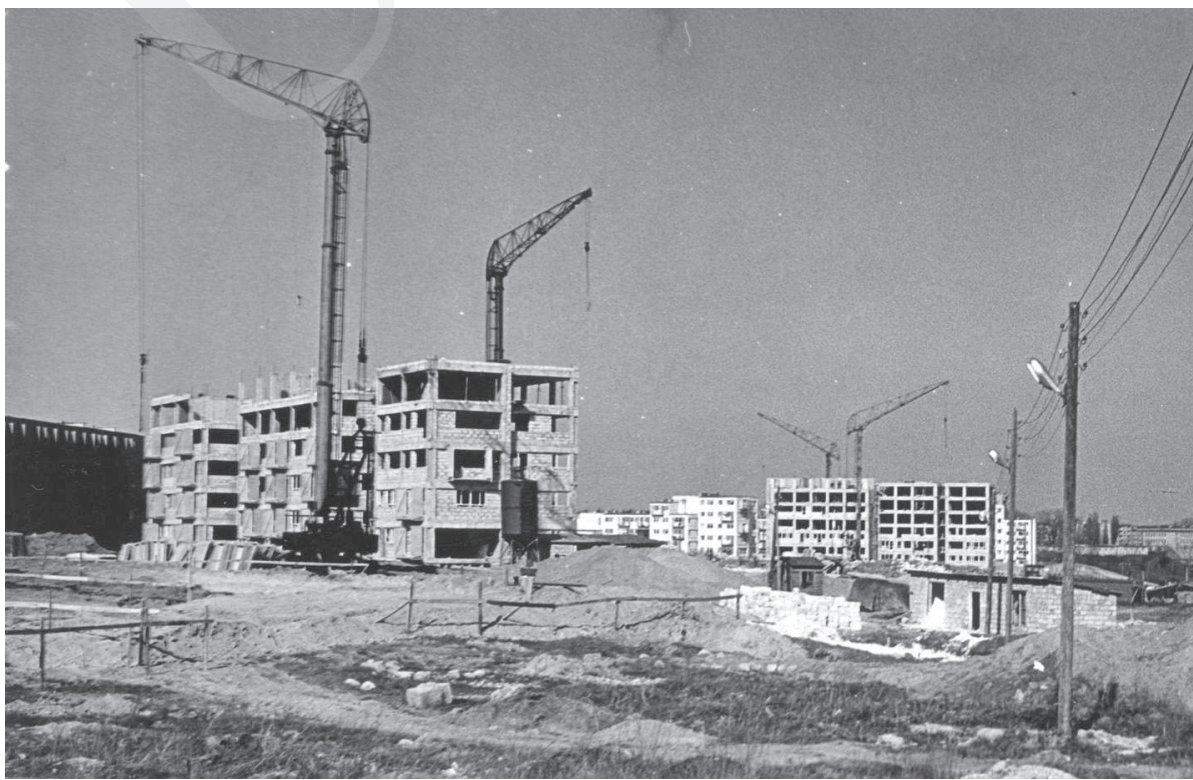

Fot. 3. LSM, budowa os. Słowackiego - widok na bloki na ul. Wileńskiej, bez daty; fot. ze zbiorów Teresy Gralewskiej, własność Fundacji Lubelska Agora Modernizmu. 
Pobrane z czasopisma Annales L - Artes http://artes.annales.umcs.pl

Data: 26/04/2023 12:52:50

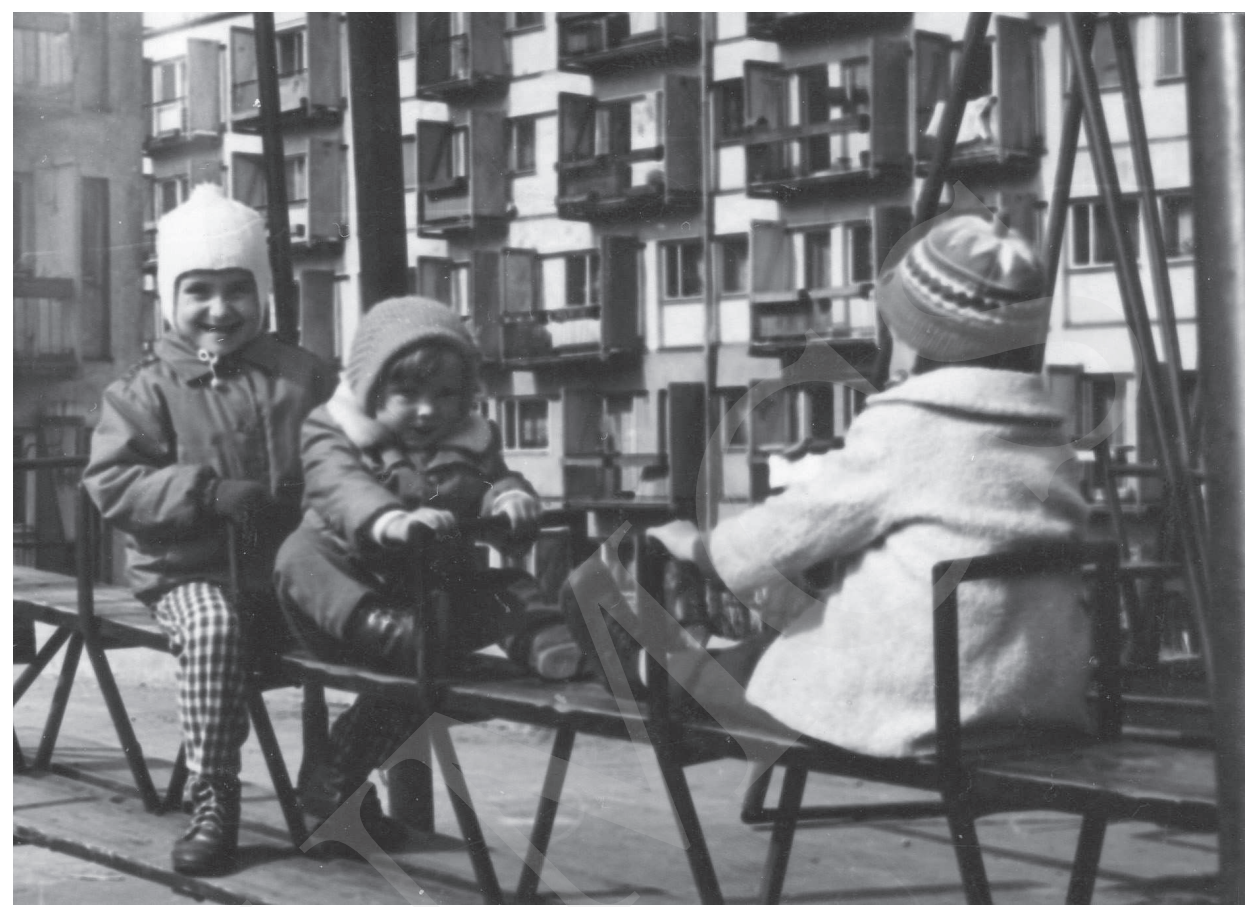

Fot. 4. LSM, plac zabaw na os. Słowackiego, 1972; fot. ze zbiorów Urszuli Śwircz, własność Fundacji Lubelska Agora Modernizmu. 